\title{
MUSCARI ARMENIACUM LEICHTLIN (GRAPE HYACINTH): PHYTOCHEMISTRY AND BIOLOGICAL ACTIVITIES REVIEW
}

\author{
DMITRY OLEGOVICH BOKOV ${ }^{1,2,3 *}$ \\ ${ }^{1}$ Department of Pharmaceutical and Natural Sciences, Sechenov First Moscow State Medical University, Moscow, Russia. ${ }^{2}$ Department \\ of Analytical, Physical and Colloid Chemistry, Sechenov First Moscow State Medical University, Moscow, Russia. ${ }^{3}$ Laboratory of Food \\ Chemistry, Federal Research Center for Nutrition, Biotechnology and Food Safety, Moscow, Russia. Email: fmmsu@mail.ru
}

Received: 10 December 2018, Revised and Accepted: 21 December 2018

ABSTRACT

This review focuses on the Muscari armeniacum Leichtlin (Asparagaceae Juss) biologically active substances composition presented in the aireal and underground parts and finding their possible therapeutic effects. The systematic review is dedicated to the composition of biologically active substances, including recent advances in the biological activity investigation, phytochemical studies, and biotechnology methods of plant material producing. Various electronic search engines such as Google, Google Scholar, scientific literature, publishing sites, and electronic databases such as PubMed, Wiley, Springer, and Science Direct had been searched and data obtained. Other online academic libraries such as E-library and specific ethnopharmacological literature had been searched systematically for more exhaustive information on the crude herbal drug. The chemical composition of M. armeniacum biologically active substances is established; it contains anthocyanins (delphinidin and cyanidin derivatives), homoisoflavonoids, polyhydroxylated pyrrolizidine alkaloids (hyacinthacines $A_{1}, A_{2}, A_{3}$, and $B_{3}$ ), oligoglycosides (muscarosides), and ribosome-inactivating proteins (musarmins). Recent physicochemical analytical procedures for components determination and hyacinthacines synthesis pathways are mentioned. Moreover, future prospects and trends in the research of this plant have been proposed. We have reviewed researches conducted on M. armeniacum especially in areas of its use in medicine, phytochemicals, biological activity, and developed analytical methods. M. armeniacum possesses antioxidant, antimutagenic activity, and specific glycosidase inhibitory activity; M. armeniacum can be used for the production of potential anticancer, antiviral, antidiabetic, and anti-obesity drugs. It should be noted that more pharmacognostic, pharmacological studies are needed for giving further information on the clinical practice and standardization procedures for the crude herbal drug.

Keywords: Muscari armeniacum, Hyacinthacine, Muscarosides, Musarmin, Homoisoflavonoids, Muscarinin A

(C) 2019 The Authors. Published by Innovare Academic Sciences Pvt Ltd. This is an open access article under the CC BY license (http://creativecommons. org/licenses/by/4. 0/) DOI: http://dx.doi.org/10.22159/ajpcr.2019.v12i1.30325

\section{INTRODUCTION}

Muscari armeniacum Leichtlin (Asparagaceae Juss) is small flowering plant in the squill subfamily (Scilloideae), also known as Hyacinthaceae family with numerous medicinal plant representatives (Ornithogalum species [1], Urginea indica [2], etc.). M. armeniacum is a bulbous perennial with simple, basal leaves, and short flowering stems. It is also known as grape hyacinth, viper onion, garden grape-hyacinth, or Armenian grape hyacinth $[3,4]$. M. armeniacum plants bloom in middle spring (April or May in the Northern areas) for 3 or 4 weeks. Established bulbs leaf in the autumn. M. armeniacum is widespread in the meadows and woods of the Eastern Mediterranean, from Greece and Turkey to the Caucasus, including Armenia [5]. M. armeniacum is popular with plant growers due to its bright flowering and unusual appearance. Some varieties are used in landscape design. M. armeniacum is an excellent honey plant; its pleasant smell attracts many bees, butterflies, and bumblebees to the garden [6].

Bulbs of M. armeniacum are suitable for human consumption in Turkey [7]. Possessing a pleasant smell, M. armeniacum found application in perfumery and cosmetology. M. armeniacum is a non-pharmacopeial plant; it is not used in official medicine. The therapeutic properties of $M$. armeniacum are known in traditional medicine. The plant is used externally as a wound healing $[8,9]$, antiseptic, an anesthetic for inflammatory processes of a dermatological nature, wounds, and burns [10]. Recent studies have shown that M. armeniacum can be used as perspective a medicinal plant in official medicine.

The aim of this research is a pharmacognostic review of M. armeniacum plants including the studying the literature for biological properties and phytochemical composition.

\section{METHODS}

Various electronic search engines such as Google, Google Scholar, scientific literature, publishing sites, and electronic databases such as PubMed, Wiley, Springer, and Science Direct had been searched and data obtained. Other online academic libraries such as E-library and specific ethnopharmacological literature had been searched systematically for more exhaustive information on the crude herbal drug.

\section{RESULTS AND DISCUSSION}

M. armeniacum (Fig. 1) is a perennial, shade-tolerant and light-loving plant that prefers moderate hydration. The height of the plants during flowering is $15-20 \mathrm{~cm}$. The bulb is fleshy, ovate, rounded, $2-3.5 \mathrm{~cm}$ in diameter, and covered with light scales. Leaves are basal, linear, beltlike, strong 10-17 cm long, and $0.5-2.5 \mathrm{~cm}$ wide. At the beginning of the growing season, up to seven leaves are produced from one bulb. Depending on the type and variety of basal leaves can be formed in spring or autumn. Stem is inflorescence shoot; it is bare, usually single (in some cases two stems appear). At the top of the stem, a dense, many-flowered, racemose inflorescence (simple raceme) $2-8 \mathrm{~cm}$ long is formed. The flowers are small $0.5-0.8 \mathrm{~cm}$, actinomorphic, fragrant, on short pedicels, tightly pressed to each other. The shape of the buds resembles a jug or barrel with six short teeth, bent outwards. Miniature flowers sit tightly on the stem; dark blue perianth has white teeth. Androecium consists of 6 stamens located in 2 circles, attached by threads to the middle of the perianth tube and hidden in it. The gynoecium is represented by a pestle with an upper three-celled ovary, with one filiform column and a capitate. Nonacetolysed pollen grains with granulate ornamentation of the sulcus membrane have the following dimensions: Long axis is $28.08 \pm 1.24$; short axis $-18.81 \pm 1.05$; it's ratio - 1.49 [11]. Fruits are sincarp, winged, angular, three-nest box, 
dorsoventrally open. Seeds are round, black, smooth, net-wrinkled, remain viable for about 1 year. Seeds are formed only in the lower part of the inflorescence since apical flowers are barren [10]. The chromosome number $(\mathrm{CN})$ is $2 \mathrm{n}=18$ (Turkey, Greek populations); in general, CNs are $2 \mathrm{n}=18,36$ [12]. Polyploid $M$. armeniacum plants $(2 \mathrm{n}=4 \mathrm{x}=36)$ were obtained by colchicine-induced chromosome reduplication [13]

M. armeniacum plants contain different groups of biologically active substances: Flavonoids, mucilages, saponins, and alkaloids among them [14-16]

The blue color of $M$. armeniacum flowers is associated with the content of anthocyanins. $p$-Coumaric acid is one of the acyl groups of muscarinin A, delphinidin-3-(6- $p$-coumaroylglucoside)-5-(4-rhamnosyl6-malonylglucoside) (Fig. 2) [19]. P450 (MaP450) gene plays a role in the anthocyanin biosynthetic pathway; as flavonoid 3'5'-hydroxylase enzyme (F3'5'H), associated with this gene, provides the expression of blue or purple color in Muscari species flowers [20]. Furthermore, MaAN2 (R2R3-MYB family AN2 subgroup) take part in anthocyanin biosynthesis [21]

Studies of anthocyanins profile in various species of Muscari (also in M. armeniacum) were conducted by several groups of researchers. M. armeniacum is a popular ornamental perennial plant that is famous for its blue flowers, but there are cultivars with white, violet-blue, purple, and red-purple flowers $[23,24]$. This colors are formed by a mixture of anthocyanins: Cyanidin, cyanidin-3-0-caffeoyl-rutinoside, cyanidin-3-0-(p-coumaroyl)-lucoside-5-0-malonyl-glucoside, malvidin-3-0-glucoside, delphinidin-3-0-glucoside, pelargonidin3-0-ferulylglucoside-5-0-arabinoside, pelargonidin-3-0-sinapylglucoside-5-O-glucoside, pelargonidin-C-O-caffeoyl-sophoroside-50-arabinoside, pelargonidin-3-0-sinapyl-glucoside-5-0-arabinoside, and petunidin-3-0-glucoside. $M$. armeniacum contains delphinidin and cyanidin derivatives [25-27]. Anthocyanins are known for their antioxidant abilities and widely represented in the plant world [28,29].

The isolation and structural clarification of homoisoflavonoids (3-benzylidene-4-chromanones with $-\mathrm{OH}$ or $-\mathrm{OCH}_{3}$ groups in the

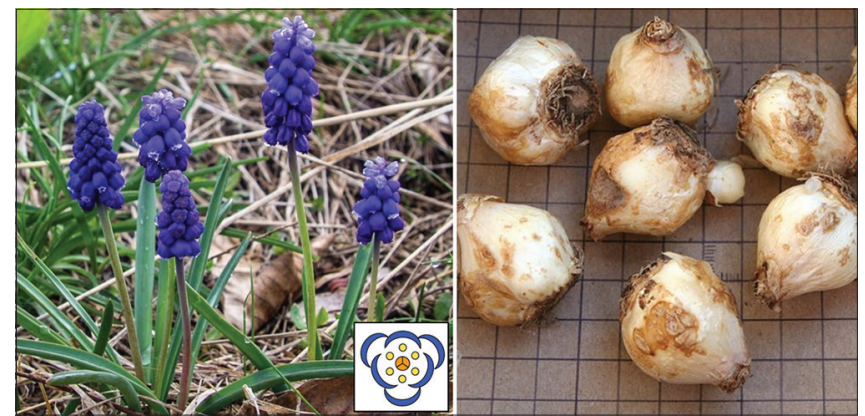

Fig. 1: Muscari armeniacum Leichtlin in flowering phase [17] with floral diagram [18] (1) and asleep bulbs [5] (2)

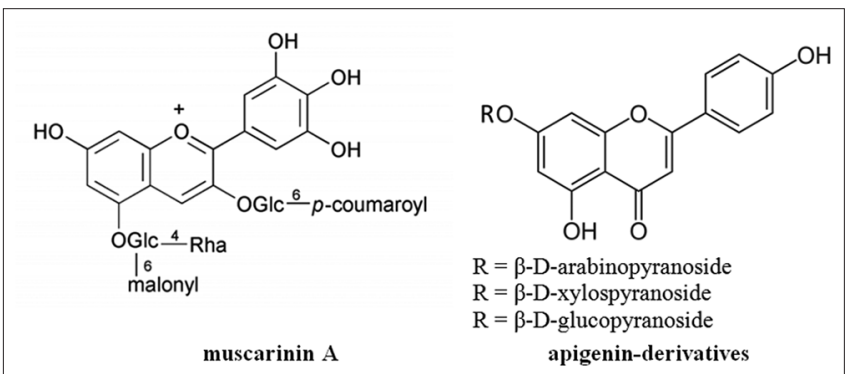

Fig. 2: Structure of muscarinin A [22] and apigenin-derivatives [14] from Muscari armeniacum
3'- and 4'- positions) was reported in M. armeniacum (Fig. 3) [30,31]. Homoisoflavonoids possess strong antioxidant activity [32] and the potential antimutagenic effect [33].

M. armeniacum flowers give off a floral, fruity, and slightly peach-like odor. 2-phenylethanol and 2-(4-methoxyphenyl)-ethanol are the main constituents of the corresponding odor concentrate. In the vacuum headspace concentrate of the $M$. armeniacum flowers such compounds as: Acetophenone (2\%), 2-phenylethanol (20\%), 1-phenylethanol (1\%), 4-hydroxylinalool (3\%), 2-(4-methoxyphenyl)-ethanol (31\%), (E,E)$\alpha$-farnesene (2\%), 1-phenylethyl benzoate (3\%), and 2-phenylethyl benzoate $(2 \%)$ were identified [34].

Analysis of nonstructural carbohydrates by high-performance anionexchange chromatography with pulsed amperometric detection in M. armeniacum bulbs collected in the Netherlands was conducted in Cornell University (Ithaca, NY, USA). Concentrations of glucose were $0.6 \pm 0.1 \mathrm{mg} / \mathrm{g}$, fructose $-4.4 \pm 0.4 \mathrm{mg} / \mathrm{g}$, sucrose $-16 \pm 2 \mathrm{mg} / \mathrm{g}$, starch - $244 \pm 1 \mathrm{mg} / \mathrm{g}$, and fructan - 362 $\pm 21 \mathrm{mg} / \mathrm{g}$ [35]. In the bulbs of $M$. armeniacum (known as Muscari szovitsianum Baker), watersoluble polysaccharide was determined, it was a neutral glucofructan containing glucose and fructose (in ratio 26:1) [36].

The content of biologically active and reserve substances in the aerial and underground parts of $M$. armeniacum was investigated by researchers from the Central Siberian Botanical Garden of the Siberian Branch of the Russian Academy of Sciences (Russia). The starch, sugar, ascorbic acid, saponins, protopectins, pectins, and catechins have been established in M. armeniacum bulbs, located in the forest-steppe zone of Western Siberia during the growing season $(2007,2009-2011)$. Flavonols were found in the leaves (1.8-2.2\%). It was established that at the pre-winter period the amount of sugar in the bulbs decreases by 2-4 times as compared with spring, and the amount of starch increases by 1.5-2 times. In May, the content of ascorbic acid in the upper-ground organs is increased by 5-10 times, sugar - 1.5 times, and catechins - 2 times than in the underground organs. It is noted that the bulbs contain 2-3 times more, and the leaves 5-6 times more protopectins than pectins. It is noted in bulbs there are 2-3 times more protopectins compared with pectins and 5-6 times more in leaves. In the aerial and underground parts of M. armeniacum the content of reserve and biologically active substances depend on the seasonal and individual factors [37].

Hyacinthacines $A_{1}, A_{2}, A_{3}$, and $B_{3}$ (Fig. 4), polyhydroxylated pyrrolizidine alkaloids, have been isolated from the bulbs of $M$. armeniacum. They possess glycosidase inhibitory activity of rat intestine lactase $\left(\mathrm{IC}_{50}=4.4-\mu \mathrm{M}\right)$, L-fucosidase $\left(\mathrm{IC}_{50}=46 \mu \mathrm{M}\right)$, and amyloglucosidase $\left(\mathrm{IC}_{50}=25 \mu \mathrm{M}\right)$ [38-41]. Hyacinthacines $\mathrm{A}_{1}, \mathrm{~A}_{2}, \mathrm{~A}_{3}$, and $\mathrm{B}_{3}$ can be obtained by various synthetic pathways [42-60].

M. armeniacum contains oligoglycosides, named muscarosides (A12, B13, G3, J6, K7, L8, and M9). They have spirocyclic nortriterpenoid aglycone that belongs to the eucosterol group (Fig. 5). The glycone moieties are presented by 4-6 units of arabinose, glucose, rhamnose, or apiose [61,62].

Musarmins (MUs) isoforms 1, 2, and 3, ribosome-inactivating protein ([RIP]; EC 3.2.2.22) [63] have been isolated from the bulbs of M. armeniacum by ion-exchange chromatography and gel filtration. MUs are single-chain proteins that were established by electrophoresis. Mass spectrometry showed Mr values of 28,708 (MU 1), 30,003 (MU 2), and 27,626 (MU 3). MUs inhibited strongly protein synthesis of mammalian ribosomes (IC50 is $0.14-0.24 \mathrm{nM}$ ) but did not inhibit protein synthesis of HeLa cells and plant cell-free systems. As opposed to other RIPs, MUs are located only in bulbs, and they are not induced in leaves. Hence, in plants these proteins may play a non-vital role; for example, as protective and anti-pathogens agents solely in some stages of the cycle in plant life [64]. The production of recombinant MU 1 was performed by bacterial expression [65]. 


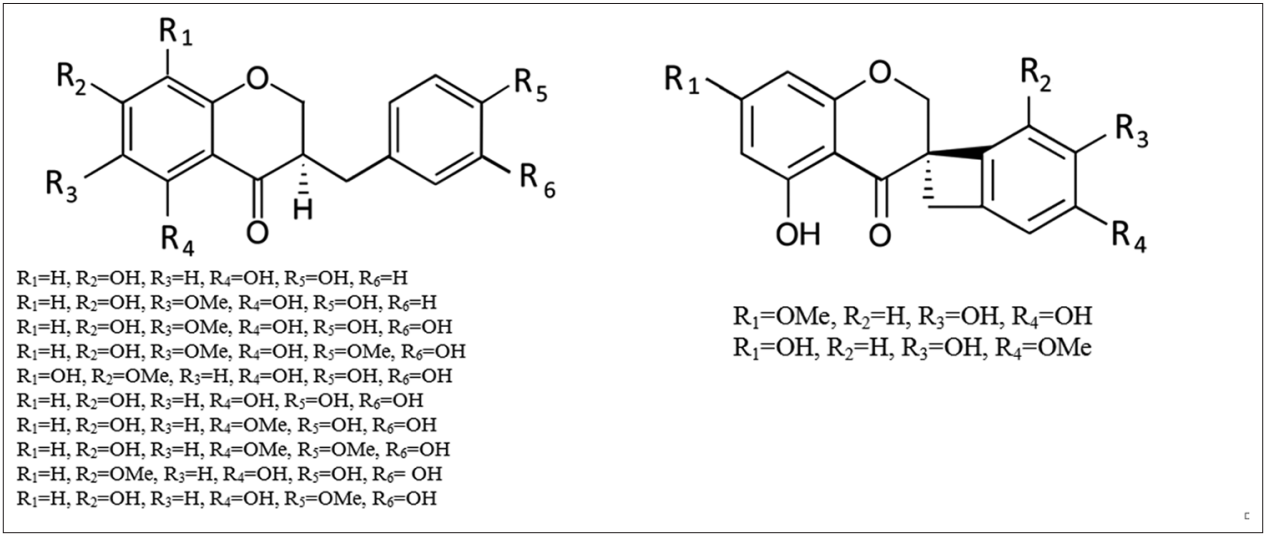

Fig. 3: Structures of homoisoflavonoids (3-benzylidene-4-chromanones) in Muscari armeniacum [14]

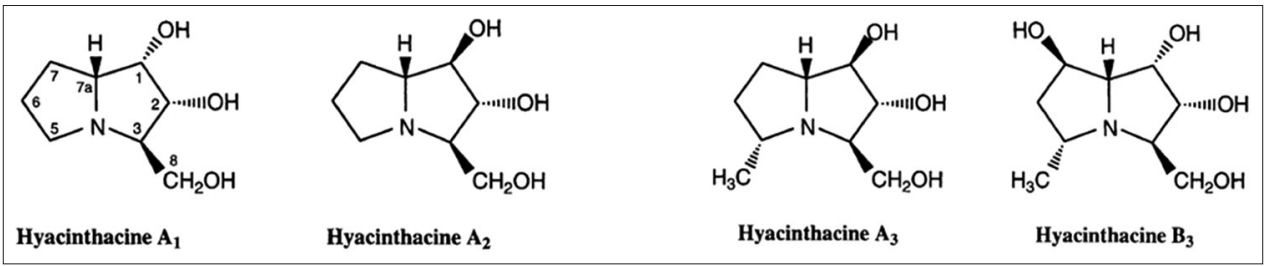

Fig. 4: Structures of polyhydroxylated pyrrolizidine isolated from Muscari armeniacum

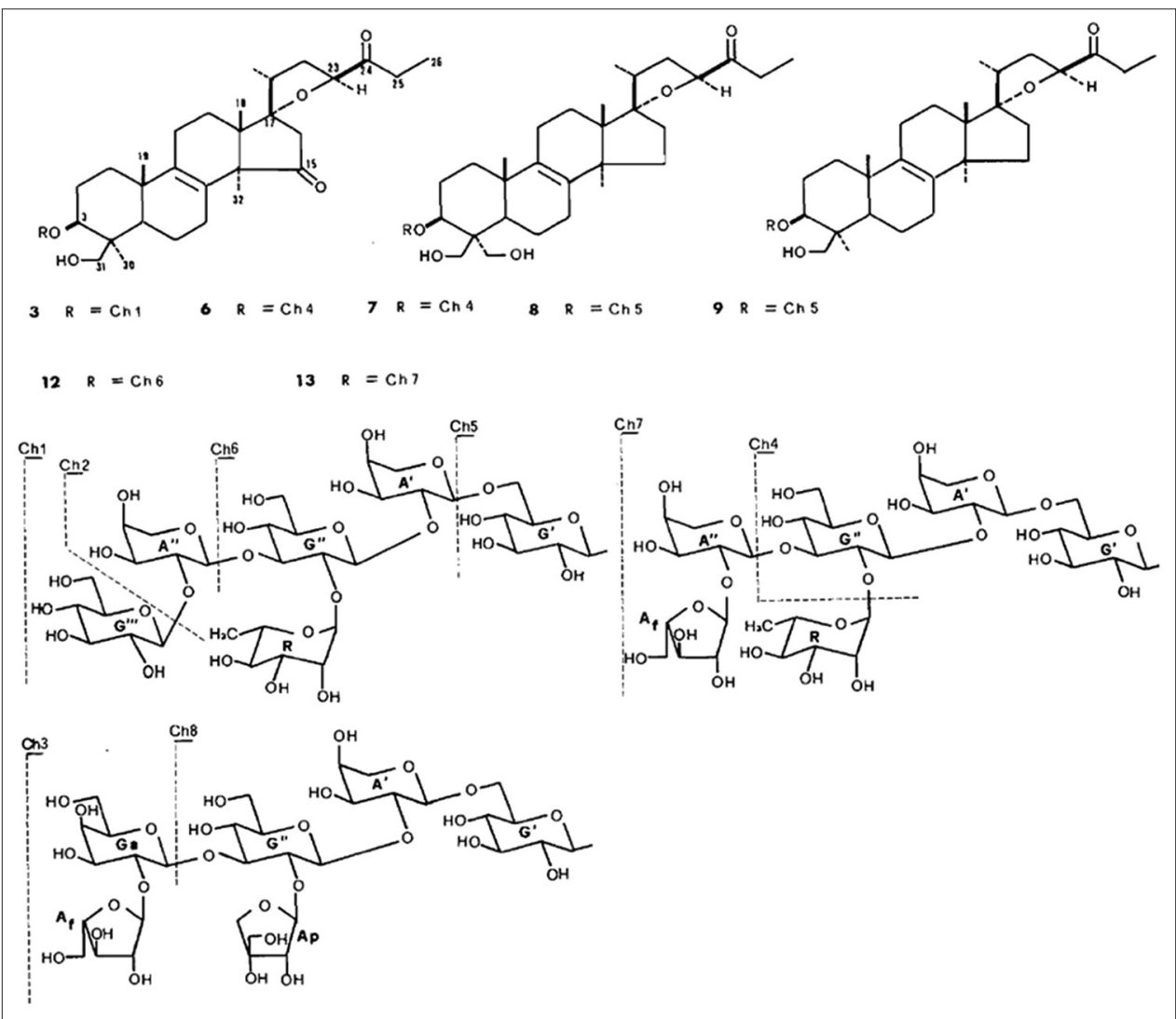

Fig. 5: Structures of muscarosides isolated from Muscari armeniacum [61]

Biotechnology (in vitro tissue culture) helps to clone material of Muscari and produce plants in volume [66]. M. armeniacum is also a good model for producing callus cultures with efficient genetic transformation system $[67,68]$; an efficient system for transgenic plants production of M. armeniacum through Agrobacterium-mediated transformation was developed [69]. The action of four potentially selective substances for transformed cells, antibiotics (geneticin, kanamycin, and hygromycin), bialaphos, antibiotics for eliminating Agrobacterium (cefotaxime and carbenicillin) on somatic embryogenesis, and growth of $M$. armeniacum ("Blue Pearl") calli was evaluated [68]. Furthermore, the system of plant regeneration from $M$. armeniacum leaf explants through somatic embryogenesis was presented [70], as well as in vitro propagation 
(regeneration) systems for this plant [71,72]. Plantlet regeneration Muscari species ("Blue Pearl") from protoplasts was successfully performed [73]. In M. armeniacum ("Early Giant") the influence of scale position, scaling time, leaf part, and leaf cutting time on growth and bulblet formation were studied $[74,75]$.

Grape hyacinth bulbs were the object for investigation of gummosis hormonal regulation. The study focused primarily on the gums chemical composition (homogenous polysaccharides) [76]. Effects of plant hormones (gibberellic acid, benzyladenine, abscisic acid, and indole3-acetic acid) were studied on inflorescence stalk and leaves growth of M. armeniacum [77] as well as cold forcing [78]. Plants freezing hardiness is an important aspect for landscape planting; M. armeniacum was resistant with median lethal dose temperature $\left(\mathrm{LT}_{50}\right)<-9^{\circ} \mathrm{C}[79]$.

In Manisa Celal Bayar University (Manisa, Turkey), the M. armeniacum anatomical features growing in west Anatolia have been investigated. Superficial transverse sections, transverse cross-sections and of leaves, scapes, and roots were prepared for identification of anatomical features of plants (M. armeniacum and Muscari neglectum) collected from nine different spreading locations. Obtained indications help to differentiate the species anatomically; differences and similarities were determined. It was shown that the scapes and roots of species are similar anatomically as for leaves have several differences [80].

\section{CONCLUSION}

M. armeniacum has a wide range of biologically active substances. Thanks to the homoisoflavonoids content, crude herbal drug can demonstrate antioxidant, antimutagenic activity and can be used for cancer prevention.

Hyacinthacine alkaloids have specific glycosidase inhibitory activities; they have been identified as potential anticancer, antiviral, antidiabetic, and antiobesity drugs [81].

It should be noted that there is a need for further research. It is necessary to study the pharmacological profile of specific chemical compounds in order to check the M. armeniacum water extracts indication in traditional medicine; and an assessment of possible action mechanisms should be made. The present review focusing on the traditional uses, phytochemistry, biology, and pharmacological properties of $M$. armeniacum gave the preliminary information for additional studies on this plant. The results of the investigation can be used for further development of procedures for routine quality control and pharmacopeial monographs for crude herbal drugs.

\section{AUTHORS' CONTRIBUTIONS}

I declare that this work was done by the author named in this article.

\section{ACKNOWLEDGMENT}

Supported by the "Russian Academic Excellence Project 5-100."

\section{CONFLICTS OF INTEREST}

None.

\section{REFERENCES}

1. Bhattacharya S, Maity S, Pramanick D, Hazra A, Choudhury M. HPLC of phenolic compounds, antioxidant and antimicrobial activity of bulbs from three Ornithogalum species available in India. Int J Pharm Pharm Sci 2016;8:187-92

2. Misra B, Kameshwari MN. Extraction and sugar composition of mucilage in Urginea indica/Drimia indica (Roxb) Kunth Hyacinthaceae. Int J Pharm Pharm Sci 2016;8:335-8.

3. Wilson CG, Mathew B. Bulbs: The Bulbous Plants of Europe and their Allies. London: Collins; 1981

4. Botanical Society of Britain and Ireland. Archived from the Original (xls). Available from: https://www.webcitation.org/6VqJ46atN?url=http://
www.bsbi.org.uk/BSBIList2007.xls. [Last accessed on 2018 Jun 06].

5. "Muscari". Pacific Bulb Society. Available from: http://www. pacificbulbsociety.org/pbswiki/index.php/muscari. [Last accessed on 2018 Jun 06].

6. Grape Hyacinth, Muscari armeniacum. Master Gardener Program. University of Wisconsin-Extension. Available from: https://www. wimastergardener.org/article/grape-hyacinth-muscari-armeniacum/. [Last accessed on 2018 Jun 06].

7. Mükemre M, Behçet L, Çakılcığlu U. Survey of wild food plants for human consumption in villages of Çatak (Van-Turkey). Indian J Tradit Knowl 2016;15:183-91.

8. Dogan A. Traditional Natural Therapeutic Products Used in the Treatment of Wound in the Tunceli (Turkey). USA: The 2016 WEI International Academic Conference Proceedings Boston.

9. Tuzlacı E, Doğan A. Turkish folk medicinal plants. IX: Ovacık (Tunceli). Marmara Pharm J 2010;14:136-43.

10. Lozina-Lozinskaya AS. Genus 283. In: Komarov VL, editor. Viper Onion-Muscari. Flora of the USSR. Vol. 4, 30. Moscow-Leningrad: Publishing House of the Academy of Sciences of the USSR; 1935. p. 412-22.

11. Pehlivan S, Ozler H. Pollen morphology of some species of Muscari Miller (Liliaceae-Hyacinthaceae) from Turkey. Flora 2003;198:200-10.

12. Karlén T. Karyotypes and chromosome numbers of five species of Muscari (Liliaceae). Willdenowia 1985;14:313-20.

13. Jia M, Wang F, Jia A, Zheng L. Colchicines induced polyploid plants of Muscari armeniacum. Acta Agric Boreali Occident Sin 2011;1:21.

14. Mulholland DA, Schwikkard SL, Crouch NR. The chemistry and biological activity of the Hyacinthaceae. Nat Prod Rep 2013;30:1165 210

15. Kayıran SD, Özkan EE, Özhatay N. The Screening Phytochemical Components of Muscari and Bellevalia species Growing in Kahramanmaras and Review of Phytochemical Studies. $11^{\text {th }}$ International Symposium on Pharmaceutical Sciences-Ankara (ISOPS 2015); 2015.

16. Kayıran SD, Özkan EE. The ethnobotanical uses of Hyacinthaceae species growing in Turkey and a review of pharmacological activities. Indian J Tradit Knowl 2017;16:243-50.

17. Plantarium. The Determinant of Plants On-Line. Open Atlas of Plants and Lichens in Russia and Adjacent Countries. Available from: http:// www.plantarium.ru/page/image/id/450309.html. [Last accessed on 2018 Oct 06].

18. Nakada M, Komatsu M, Ochiai T, Ohtsu K, Nakazono M, Nishizawa NK, et al. Isolation of MaDEF from Muscari armeniacum and analysis of its expression using laser microdissection. Plant Sci 2006;170:143-50.

19. Yoshida K, Aoki H, Kameda K, Kondo T. Structure of muscarinin A, an acylated anthocyanin, from purplish blue spicate flower petals of Muscari armeniacum. ITE Lett Batter New Technol Med 2002;1:35-8.

20. Mori S, Nakano M, Kondo M, Hoshi Y, Kobayashi H. Isolation and characterization of a cytochrome $\mathrm{P} 450$ gene from Muscari armeniacum. Acta Hortic 2005;673:429-35.

21. Chen K, Liu H, Lou Q, Liu Y. Ectopic expression of the grape hyacinth (Muscari armeniacum) R2R3-MYB transcription factor gene, MaAN2, induces anthocyanin accumulation in tobacco. Front Plant Sci 2017;8:965

22. Williams CA, Grayer RJ. Anthocyanins and other flavonoids. Nat Prod Rep 2004;21:539-73.

23. Wraga K, Placek M. Review of taxons from genus Muscari cultivated in department of ornamental plants in Szczecin. Herba Pol 2009;55:348-53.

24. Dashwood M, Mathew B. Hyacinthaceae-Little Blue Bulbs. Bulletin Number 11. RHS Plant Trials and Awards. Royal Horticultural Society; 2005. Available from: https://www.rhs.org.uk/Plants/PDFs/Planttrials-and-awards/Plant-bulletins/hyacinthaceae.pdf. [Last accessed on 2018 Nov 08].

25. Lou Q, Wang L, Liu H, Liu Y. Anthocyanin profiles in flowers of grape Hyacinth. Molecules 2017;22:688.

26. Mori S, Asano S, Kobayashi H, Nakano M. Analyses of anthocyanidins and anthocyanins in flowers of Muscari spp. Bulletin of the Faculty of Agriculture-Niigata University (Japan) 2002;551:13-8.

27. Lou Q, Liu Y, QiY, Jiao S, Tian F, Jiang L, et al. Transcriptome sequencing and metabolite analysis reveals the role of delphinidin metabolism in flower color in grape hyacinth. J Exp Bot 2014;65:3157 64 .

28. Sivamaruthi B, Pengkumsri N, Saelee M, Kesika P, Sirilun S, Peerajan S, et al. Impact of physical treatments on stability and radical scavenging capacity of anthocyanidins. Int J Pharm Pharm Sci 2015;8:162-7.

29. Joshi S, Jadhav V, Kadam V. Exotic fruits and vegetable food as nutritional supplement for diabetes, obesity and metabolic diseases. Int J Curr Pharm Res 2018;10:51-5. 
30. Adinolfi M, Corsaro MM, Lanzetta R, Laonigro G, Mangoni L, Parrilli M. Ten homoisoflavanones from two Muscari species. Phytochemistry 1986;26:285-90.

31. Grancaiová Z, Mašterová I, Suchý V. Constituents of Muscari armeniacum. Fitoterapia 1992;63:380.

32. Juránek I, Suchý V, Stará D, Maśterová I, Grancaiova Z. Antioxidative activity of homoisoflavonoids from Muscari racemosum and Dracena cinnabari. Pharm 1993;48:310.

33. Miadoková E, Mašterová I, Vlčková V, Dúhová V, Tóth J. Antimutagenic potential of homoisoflavonoids from Muscari racemosum. J Ethnopharmacol 2002;81:381-6.

34. Surburg H, Guentert M, Harder H. Volatile Compounds from Flowers: Analytical and Olfactory Aspects. Bioactive Volatile Compounds from Plants. In ACS Symposium Series (USA); 1993. p. 168-86.

35. Ranwala AP, Miller WB. Analysis of nonstructural carbohydrates in storage organs of 30 ornamental geophytes by high-performance anionexchange chromatography with pulsed amperometric detection. New Phytol 2008;180:421-33.

36. Barbakadze VV, Targamadze IL, Usov AI. Glucofructan from bulbs of grape hyacinth Muscari szovitsianum Baker (Liliaceae). Bioorg Khim 1996;22:441-5.

37. Sedelnikova LL, Kukushkina TA. The content of reserve and biologically active substances in the vegetative organs of Armenian Muscari (Muscari armeniacum). Chem Sustain Dev 2016;24:647-51.

38. Asano N, Kuroi H, Ikeda K, Kizu H, Kameda Y, Kato A, et al. New polyhydroxylated pyrrolizidine alkaloids from Muscari armeniacum: Structural determination and biological activity. Tetrahedron Asymmetry 2000;11:1-8.

39. Asano N, Nash RJ, Molyneux RJ, Fleet GW. Sugar-mimic glycosidase inhibitors: Natural occurrence, biological activity and prospects for therapeutic application. Tetrahedron Asymmetry 2000;11:1645-80.

40. Watson AA, Fleet GW, Asano N, Molyneux RJ, Nash RJ. Polyhydroxylated alkaloids-natural occurrence and therapeutic applications. Phytochemistry 2001;56:265-95.

41. Ritthiwigrom T, Au CW, Pyne SG. Structure, biological activities and synthesis of hyacinthacine alkaloids and their stereoisomers. Curr Org Synth 2012;9:583-612.

42. Chabaud L, Landais Y, Renaud P. Total synthesis of hyacinthacine A1 and 3-epi-hyacinthacine A1. Org Lett 2005;7:2587-90.

43. Reddy PV, Veyron A, Koos P, Bayle A, Greene AE, Delair P. Approach to the hyacinthacines: First non-chiral pool synthesis of $(+)$-hyacinthacine A1. Org Biomol Chem 2008;6:1170-2.

44. Chandrasekhar S, Parida BB, Rambabu C. Total synthesis of hyacinthacine A1, a glycosidase inhibitor. J Org Chem 2008;73:7826-8.

45. Si CM, Mao ZY, Ren RG, Du ZT, Wei BG. Flexible approach for the asymmetric synthesis of (-)-hyacinthacine A1 and its 7a-epimer. Tetrahedron 2014; 70:7936-41.

46. Calveras J, Casas J, Parella T, Joglar J, Clapés P. Chemoenzymatic synthesis and inhibitory activities of hyacinthacines A1 and A2 stereoisomers. Adv Synth Catal 2007;349:1661-6.

47. D’Adamio G, Goti A, Parmeggiani C, Moreno-Clavijo E, Robina I, Cardona F. Total synthesis of (+)-hyacinthacine A1,(+)-7a-epihyacinthacine A1,6R)-6-hydroxyhyacinthacine A1 and (6S)-6hydroxy-7a-epi-hyacinthacine A1. Eur J Org Chem 2011;35:7155-62.

48. Ribes C, Falomir E, Carda M, Marco JA. Stereoselective syntheses of the glycosidase inhibitors hyacinthacine A2, hyacinthacine A3 and 5-epi-hyacinthacine A3. Tetrahedron 2009;65:6965-71.

49. Liu XK, Qiu S, Xiang YG, Ruan YP, Zheng X, Huang PQ. SmI2mediated radical cross-couplings of $\alpha$-hydroxylated aza-hemiacetals and N, S-acetals with $\alpha, \beta$-unsaturated compounds: Asymmetric synthesis of (+)-hyacinthacine A2,(-)-uniflorine A, and (+)-7-epicasuarine. J Org Chem 2011;76:4952-63

50. Izquierdo I, Plaza MT, Franco F. Polyhydroxylated pyrrolizidines. Part 3: A new and short enantiospecific synthesis of (+)-hyacinthacine A2. Tetrahedron Asymmetry 2003; 14:3933-5.

51. Duarte MO, Stedele G, Pazinatto M, de Oliveira ER, Eifler-Lima VL. New solid-phase approach to synthesize a hyacinthacine core using the L-proline as a building block. Lett Org Chem 2009;6:90-3.

52. Dewi-Wülfing $P$, Blechert S. Enantiospecific synthesis of (+)hyacinthacine A2. Eur J Org Chem 2006;8:1852-6.

53. Rambaud L, Compain P, Martin OR. First total synthesis of (+)-hyacinthacine A2. Tetrahedron Asymmetry 2001;12:1807-9.

54. Cardona F, Faggi E, Liguori F, Cacciarini M, Goti A. Total syntheses of hyacinthacine A2 and 7-deoxycasuarine by cycloaddition to a carbohydrate derived nitrone. Tetrahedron Lett 2003;44:2315-8.

55. Desvergnes S, Py S, Vallée Y. Total synthesis of (+)-hyacinthacine A2 based on SmI2-induced nitrone umpolung. J Org Chem
2005;70:1459-62.

56. Delso I, Tejero T, Goti A, Merino P. Synthesis of D-arabinose-derived polyhydroxylated pyrrolidine, indolizidine and pyrrolizidine alkaloids. Total synthesis of hyacinthacine A2. Tetrahedron 2010;66:1220-7.

57. Royzen M, Taylor MT, De Angelis A, Fox JM. Total synthesis of hyacinthacine A2: Stereocontrolled 5-aza-cyclooctene photoisomerization and transannular hydroamination with planar-topoint chirality transfer. Chem Sci 2011;2:2162-5.

58. Izquierdo I, Plaza MT, Franco F. Polyhydroxylated pyrrolizidines. Part 2: The first total synthesis of (+)-hyacinthacine A3. Tetrahedron Asymmetry 2002;13:1581-5.

59. Liu WJ, Ye JL, Huang PQ. A flexible approach for the asymmetric syntheses of hyacinthacines A 2, A 3 and structural confirmation of hyacinthacine A3. Org Biomol Chem 2010;8:2085-91.

60. Christopher WG. Synthesis of hyacinthacine B3 and purported hyacinthacine B 7. Chem Commun 2010;46:713-5.

61. Adinolfi M, Barone G, Corsaro MM, Mangoni L, Lanzetta R, Parrilli M. Glycosides from Muscari armeniacum and Muscari botryoides. Isolation and structure of muscarosides G-N. Can J Chem 1988;66:2787-93.

62. Mahato SB, Nandy AK. Triterpenoid saponins discovered between 1987 and 1989. Phytochemistry 1991;30:1357-90.

63. Stirpe F. Ribosome-inactivating proteins. Toxicon 2004;44:371-83.

64. Arias FJ, Antolín P, de Torre C, Barriuso B, Iglesias R, Rojo MA, et al. Musarmins: Three single-chain ribosome-inactivating protein isoforms from bulbs of Muscari armeniacum L. and Miller. Int J Biochem Cell Biol 2003;35:61-78.

65. Antolín P, Girotti A, Arias FJ, Barriuso B, Jiménez P, Rojo MA, et al. Bacterial expression of biologically active recombinant musarmin 1 from bulbs of Muscari armeniacum L. and Miller. J Biotechnol 2004;112:313-22.

66. da Silva JA, Dobranszki J. Tissue culture of Muscari species: Present achievements and future perspectives. Rend Lincei 2016;27:427-41.

67. Suzuki S, Nakano M. Organogenesis and somatic embryogenesis from callus cultures in Muscari armeniacum Leichtl. Ex Bak. In Vitro Cell Dev Biol Plant 2001;37:382-7.

68. Suzuki S, Nakano M. Effects of antibiotics and bialaphos on the growth and development of embryogenic callus cultures of Muscari armeniacum. Biol Plant 2003;47:425-7.

69. Suzuki S, Nakano M. Agrobacterium-mediated production of transgenic plants of Muscari armeniacum Leichtl. Ex Bak. Plant Cell Rep 2002;20:835-41

70. Wang S, Yang F, Jiu L, Zhang W, Zhang W, Tian Z, et al. Plant regeneration via somatic embryogenesis from leaf explants of Muscari armeniacum. Biotechnol Biotechnol Equip 2013;27:4243-7.

71. Azad MA, Amin MN. Effects of hormonal and basal nutrient medium on in vitro regeneration of an ornamental plant-Muscari armeniacum Leichtlin. Ex Baker. Plant Tissue Cult Biotechnol 2012;22:113-26.

72. Yücesan BB, Cicek F, Gürel E. Somatic embryogenesis and encapsulation of immature bulblets of an ornamental species, grape hyacinths (Muscari armeniacum Leichtlin ex Baker). Turk J Agric For 2014;38:716-22.

73. Nakano M, Tanaka S, Kagami S, Saito H. Plantlet regeneration from protoplasts of Muscari armeniacum Leichtl. ex Bak. Plant Biotechnol 2005;22:249-51.

74. Bae H, Ahn H, Park S, Yue W, Jung W, Chang Y, et al. Effect of scaling time and scale position on bulblet formation in scaling of Muscari armeniacum 'early giant'. J Korean Soc Hortic Sci 2000;41:93-5.

75. Choi S, Park S, Jung W, Ahn H, Park I, Chang Y, et al. Effect of leaf cutting time and leaf part on bulblet formation of Muscari armeniacum 'early giant'. J Korean Soc Hortic Sci 2000;41:87-9.

76. Miyamoto K, Kotake T, Sasamoto M, Saniewski M, Ueda J. Gummosis in grape hyacinth (Muscari armeniacum) bulbs: Hormonal regulation and chemical composition of gums. J Plant Res 2010;123:363-70.

77. Saniewski M, Góraj-Koniarska J, Węgrzynowicz-Lesiak E, Gabryszewska E. Hormonal regulation of the growth of leaves and inflorescence stalk in Muscari armeniacum Leichtl. Acta Agrobot 2016;69:1654.

78. Hanks GR, Jones SK. The cold requirement for forcing Muscari and related plants. Sci Hortic 1987;32:287-96.

79. Inamoto K, Matsubara K, Doi M, Imanishi H. Evaluation of Freezing Hardiness of Ornamental Geophytes. Vol. 886. In $10^{\text {th }}$ International Symposium on Flower Bulbs and Herbaceous Perennials; 2008. p. 105-12.

80. Gürsoy M, Şı L. Comparative anatomical studies on Muscari armeniacum Leichtlin ex Baker and Muscari neglegtum Guss. In West Anatolia. CBU J Sci 2010;6:61-72.

81. Savaspun $\mathrm{K}, \mathrm{Au} \mathrm{CW}$, Pyne SG. Total synthesis of hyacinthacines B3, B4, and B5 and purported hyacinthacine B7, 7-epi-hyacinthacine B7, and 7a-epi-hyacinthacine B3 from a common precursor. J Org Chem 2014;79:4569-81. 